\title{
Current trends in protected cultivation in Mediterranean
}

\section{climates}

\author{
J.A. Fernández ${ }^{1}$, F. Orsini², E. Baeza ${ }^{3}$, G.B. Oztekin ${ }^{4}$, P. Muñoz ${ }^{5}$, J. Contreras ${ }^{1}$ and J.I. Montero ${ }^{5}$ \\ ${ }^{1}$ Producción Vegetal, E.T.S. Ingeniería Agronómica, Universidad Politécnica de Cartagena, Cartagena, Spain \\ ${ }^{2}$ Research Centre on Urban Environment for Agriculture and Biodiversity, Agricultural Sciences Department, Alma Mater \\ Studiorum, University of Bologna, Bologna, Italy \\ ${ }^{3}$ Wageningen UR, Greenhouse Horticulture, Wageningen, The Netherlands \\ ${ }^{4}$ Ege University, Faculty of Agriculture, Department of Horticulture, Bornova-Izmir, Turkey \\ ${ }^{5}$ Institut de Recerca i Tecnología Agroalimentaries, Cabrils, Spain
}

\section{Summary}

Protected cultivation has rapidly expanded in many regions all over the world, particularly in those with mild winter climatic conditions. In this context, the greenhouse industry is continually developing new strategies and technologies to solve specific cultivation limitations, to reduce any related environmental impact and to adjust to new market requirements. It is for this reason that it is necessary to update the scientific knowledge of this industry. The characteristics of greenhouse production related to new developments in structures and climate control, crops, cultivation techniques, water and nutrient management and environmental issues, including life cycle assessment and integrated pest management, are the objective of this study. Overall, the main results of this review demonstrate that a great effort of innovation and research has been carried out by industry and researchers in order to cut production costs and to reduce the environmental impact of the most advanced greenhouse technologies while satisfying the requirements of consumers.

\section{Keywords}

greenhouse pest control, soilless culture, soil fertility, plant nutrition, water quality, grafting, passive greenhouse, cladding material

\section{Introduction}

Greenhouse production in mild winter climates is mainly based on low-technology cold greenhouses, whose main traits are their simple construction characteristics and technologies, a low level of automation and mechanization, and a lack of devices for controlling environmental parameters. Consequently, there is a very strong and direct dependence of the microclimate in these greenhouses on external climatic conditions (Baille, 2001). However, the greenhouse industry and growers are continually developing new strategies and technologies to solve specific limitations related to improving solar radiation capture, particularly in winter, reducing excessive temperatures when appropriate and increasing winter night-time temperatures in the most economically feasible way. But new technologies have to be economically sound as well as being environmentally friendly (Montero et al., 2009).

\section{Significance of this study}

What is already known on this subject?

- Greenhouse production in Mediterranean climates is mainly based on low-technology cold greenhouses.

What are the new findings?

- This review highlights several new findings related to the new approaches and technologies to solve specific cultivation limitations, to reduce any related environmental impact and to adjust to new market requirements of the greenhouse industry.

What is the expected impact on horticulture?

- This review could help to update the most relevant recent developments in greenhouse structure and climate control, cropping and cultivation techniques, water and nutrient management and environmental issues including LCA and IPM in protected cultivation in Mediterranean climates.

The protected cultivation industry in mild winter climates is mainly involved in vegetable growing, usually Solanacea (tomato, pepper and eggplant) and Cucurbitacea (melon, summer squash, watermelon and cucumber), although floricultural and ornamental crops have also gradually increased in importance in recent years. In addition, in the last decade, fruit tree crops have been incorporated in this industry. However, in all cases, there is a continuing need for crop diversification in order to supply the market with new products. There have been several advances in some cultivation techniques in recent years, which are aimed at enhancing production and maximizing economic returns (Tüzel, 2013).

In general, water for irrigation is a scarce resource in countries with mild winter climates. Moreover, the increased application of fertilizers accompanied by extreme drought periods can increase salinization of the available water. Thus, optimal management is required to ensure unrestricted growth and a yield that is close to the maximum potential, while minimizing losses to the environment. In this respect, the accurate monitoring of crop mineral status to prevent nutritional imbalances is a step forward.

As in other industries, environmental concerns are driving development in greenhouse production. Life cycle assessment (LCA) has become a popular tool as an objective and transparent methodology to quantify and assess 
environmental burdens of products and services (Antón et al., 2005). LCA has been applied to greenhouse production and the main factors responsible for environmental impact have been identified, particularly those related with the "bottleneck" of Mediterranean horticulture (Antón et al., 2005; Martínez-Blanco et al., 2011).

The implementation of integrated pest management (IPM) techniques contributes to greater food security. The fact that the percentage of food samples free of residues is increasing points to the increasingly rational use of pesticides. However, the problem of pests in agriculture is far from being solved, and our guard must not be lowered in this respect.

Studies over the past two decades have provided important information on the trends in in protected cultivation in Mediterranean climates (e.g., Montero et al., 2009; Baudin et al., 2013; Tüzel and Oztekin, 2016; Baeza and Kacira, 2017; De Pascale et al., 2017). However, this industry is constantly evolving and progress is continuous. Thus, this paper discusses the most relevant recent developments in greenhouse structure and climate control, cropping and cultivation techniques (more specifically, grafting and fruit-setting), water and nutrient management and environmental issues including LCA and IPM in protected cultivation in Mediterranean climates.

\section{Technological trends in greenhouse structures and climate control}

\section{New greenhouse structures}

The goal for Mediterranean greenhouses is to use available natural resources, such as solar radiation and temperature, wisely, while not relying on external energy sources. Traditional greenhouses do not achieve such goal, and so, research efforts have been focused on developing innovations in three main critical aspects:

- Improving solar radiation transmission in winter.

- Reducing excessive day-time temperature.

- Increasing winter night-time temperature without using external energy.

Productivity is directly proportional to accumulated solar radiation (Heuvelink, 2005), and so, greenhouse transmissivity to solar radiation is important. Well-designed greenhouses have better light transmission than traditional greenhouses, which have about 55\% transmissivity. For instance, Soriano et al. (2004) reported transmissivity of around 65\% in greenhouses with increased roof slope, and García et al. (2011) presented transmissivity of $70 \%$ in a multi-tunnel greenhouse in Southern Spain.

Several studies have been carried out to improve greenhouse transmissivity. Conclusions show that, in terms of roof shape, a symmetrical flat roof with a $30^{\circ}$ slope is a good compromise between transmissivity and construction costs, there being little benefit in increasing the roof slope or in erecting asymmetrical greenhouses (Castilla, 2013). In terms of orientation, an east-west orientation is preferred to northsouth since it is more transmissive, although light uniformity is better in N-S oriented greenhouses (Castilla, 2013).

Hernandez (2009) compared the transmissivity of multi-tunnel and flat roof greenhouses with a similar slope (approximately $23^{\circ}$ ), finding no relevant differences (only $1.3 \%$ more transmission in winter for the curved shape). Interestingly, the study by Hernandez also showed the negative effects of flap roof ventilators in light transmission. When roof ventilators are widely open, the roof geometry becomes horizontal in the ventilator area. This produces a reduction in light transmission of as much as $7.4 \%$ in the winter months. Rolling ventilators do not have this problem, but flap vents are more efficient than rolling vents in terms of air exchange.

Experimental data show that, in terms of tomato yield, the improvement factor of a well-designed greenhouse compared with a traditional greenhouse can be up to three times (Raya-Ramallo, 2014). Such improvement is mostly based on better light transmission and better ventilation.

\section{Natural ventilation and other cooling methods}

Natural ventilation is the most essential tool that growers can use to maintain the greenhouse microclimate (temperature, humidity and $\mathrm{CO}_{2}$ ) within the best ranges for the crop. The greenhouse is essentially a solar collector and only a tiny fraction of the solar energy entering the greenhouse is converted into dry matter by photosynthesis. Most of the energy becomes sensible or latent heat by means of plant transpiration. When the sensible heat load is too high, the greenhouse temperature becomes too high and must be decreased by ventilating (Vox et al., 2010; Giacomelli et al., 2012) . When relative humidity becomes too high, ventilation can decrease it as external air is usually drier. Finally, natural ventilation can avoid $\mathrm{CO}_{2}$ depletion if the greenhouse $\mathrm{CO}_{2}$ concentration is lower than that of external air.

During the last decade, research has widened our knowledge on how to optimize natural ventilation design in Mediterranean greenhouses. Especially, the extensive use of simulation tools like computational fluid dynamics has allowed for a better understanding of air exchange processes and their influence on the homogeneity and internal air circulation inside the greenhouse as well as the effect of different geometrical aspects (including configuration of the vents) of the greenhouse on the efficacy of the air exchange through natural ventilation, as extensively reviewed by Norton et al. (2007) and Bournet and Boulard (2010). Recent research has highlighted the important effect of wind direction in relation to the greenhouse vents on multispan greenhouses (Teitel et al., 2008). When comparing windward with leeward ventilation, research indicates that for different types of greenhouses, when flap roof vents are used, windward ventilation provides higher ventilation rates than leeward ventilation, although climate uniformity under windward ventilation is lower than under leeward ventilation (Pérez-Parra et al., 2004; Boulard and Fatnassi, 2005; Ould Khaoua et al., 2006). In other studies, parallel wind was compared to perpendicular wind. In most of these studies, higher ventilation rates are obtained when vents are perpendicular to dominant wind than when parallel (Shklyar and Arbel 2004; Hong et al., 2008).

Another usual question is whether it is always advisable to combine sidewall and roof vents. Many research studies have been conducted in small greenhouses, such as mono-span tunnels. In this type of greenhouse, research clearly indicates that combining sidewall and roof vents maximizes air exchange (Bartzanas and Kittas, 2001; Montero et al., 2001; Bartzanas et al., 2004). Similarly, in multispan greenhouses, when size is limited to a few spans, the combination of sidewall and roof vents is also the most efficient (Kacira et al., 1998), especially when wind velocity is low, where sidewall vent is critical (Baeza et al., 2009). As the greenhouse becomes larger, the relative contribution of the sidewall vent to natural ventilation is minimized in relation to the contribution of the roof vents (Kacira et al., 2004; Baeza, 2007). When the ratio of roof vent area to sidewall vent is higher than 5 (e.g., in large greenhouses of more than 1 ha), little 
benefit is obtained from sidewall vents (Baeza, 2007). Other aspects of the geometry, such as greenhouse height of roof slop have also been analyzed by means of CFD. Baeza (2007) showed that increasing the greenhouse roof slope to $25-30^{\circ}$ increases the ventilation rate by almost a factor of two and improves cooling of the crop area inside the greenhouse. An important aspect that can greatly affect the efficacy of greenhouse natural ventilation is the presence of neighboring buildings. Using CFD, Gómez-Mataix et al. (2013) found out that neighboring greenhouses or buildings have indeed a strong effect by both decreasing the ventilation rate and changing the internal airflow patterns. Ideally, greenhouse should be free of obstacles for at a least $20 \mathrm{~m}$ all around.

Of the other cooling methods, shading (e.g., whitewash) is the most used in the Mediterranean region, where it is preferred to screens due to its lower price. The challenge for shading is to develop more efficient selective shading (i.e., NIR reflecting) and or double purpose screens (shading and energy saving). Evaporative cooling systems (fogging, pad and fan, etc.) can consume large amounts of good quality water which is a very scarce resource in many regions of the Mediterranean, so their use is only justified in high-value crops or nurseries. Active cooling using cold water (chillers) is simply too expensive to be considered in the Mediterranean region.

\section{Greenhouse cladding materials}

The vast majority of Mediterranean greenhouses rely on plastic film covers, as they are cheaper than rigid materials and adaptable to all kinds of structures. Polyethylene is by far the most commonly used material. For growers, the optical properties of the film are the most important, followed by mechanical properties and durability (Baeza and López, 2012; Papadakis et al., 2000). For growers in the Mediterranean, durability of the plastic is a major issue, as the price of replacing plastic is quite high. At present, most commercial greenhouses use plastic film with additives that stabilize them against UV, and chemicals, such as sulphur and chloride, which can extend their use to a maximum of four growing seasons (Schettini and Vox, 2012; Schettini et al., 2014; Adelhafidi et al., 2015). It is a challenge to produce more lasting materials, such as fluoropolymeric, without increasing the price (Stefani et al., 2007). The beneficial effect of diffuse light on greenhouse yield is a well proven fact (e.g., Elings et al., 2012). However, for most commonly used films, high haze is obtained at the expense of a drop in hemispherical light transmission. Thus, obtaining films that combine a large hemispherical transmission and high haze at lower price than existing materials (e.g., diffusive ETFE) is a major challenge (Hemming et al., 2008). One of the disadvantages of plastic films used as greenhouse covering in comparison to glass is their hydrophobic behaviour, which leads to undesirable drop-like condensation (Gbiorczyk et al., 2002). So far, this problem has been partially solved by adding anti-fog additives, such as non-ionic surfactants. The anti-fog effect quality changes during the lifetime of the film, because the surfactants are extracted by the condensed water and the anti-fog effect disappears usually over two agricultural seasons (Espi et al., 2006). A big challenge for the future is to produce a PE film with stable anti-dripping properties throughout the life of the film (https://www.google.com/patents/ W02017045199A1?cl=en). In the Mediterranean region, double inflated polyethylene covers are still widely used, for energy saving purposes and structural reasons, despite of the large decrease in PAR transmission which leads to a large decrease of yield (e.g., Papadopoulos and Hao, 1997). A promising development in this field could be the development of PE films with large air bubbles that can perform better (in terms of thermal insulation and PAR transmission) than double inflated PE (https://www.solawrapfilms.com/). Other challenges include the development of more specific UV filters that limit infestation by pests without affecting the activity of pollinators (Baeza and Lopez, 2012). Finally, covering materials in the future should incorporate filters that can be activated (switchable) to modify almost instantaneously the properties of the cover, and adapt it to the instantaneous requirements of the crops. The trigger can be the temperature of the material or an applied voltage, among other possibilities. An interesting development in this field would be a switchable filter (e.g., activated by electricity) capable of activating high NIR reflection, while keeping PAR reflection as low as possible. In this way, NIR would be transmitted during the cold periods to enhance passive thermal energy storage, and reflected during the warm period as selective shading (Khandelwal et al., 2016). Another interesting possibility would be switchable filters capable of reflecting thermal infra-red radiation during cold winter nights, preventing the energy stored in the greenhouse from being lost, but transmitting this radiation during the daytime in the warm season to help cool the greenhouse (El Mouedden et al., 2012).

\section{Energy storage in passive greenhouses}

Greenhouses have very little thermal inertia; as soon as the sun sets, the greenhouse air temperature drops quickly (Piscia, 2012). As a consequence, the winter greenhouse microclimate is usually suboptimal due to low night temperatures. Besides, active heating is usually uneconomical (Stanghellini et al., 2016). Three major approaches can be followed to increase night-time temperature by passive means: using (internal or external) screens, closing the greenhouse vents as much as possible and increasing the greenhouse thermal inertia.

Screens act as a barrier for the exchange of far infrared radiation (FIR). Such FIR exchange controls the energy losses from the greenhouse at night (Baille et al., 2006). Based on CFD simulations, Piscia (2012) observed that an air chamber was created above the screen, which insulated the crop area from the colder roof. Temperature gains in screened unheated greenhouses range from 2 to $3^{\circ} \mathrm{C}$ for clear skies to almost zero for overcast sky. Similar effect (up to $3^{\circ} \mathrm{C}$ ) is produced by an external movable screen generally used for shading (Montero et al., 2013).

Semi-closed greenhouses aim to have minimal winter ventilation to increase the greenhouse mean daily temperature. This involves a risk of $\mathrm{CO}_{2}$ depletion (which can be compensated with $\mathrm{CO}_{2}$ enrichment) and producing excessive humidity (Baptista, 2007). Some innovative plastic-covered greenhouses are constructed to collect condensation, but in some cases, they cannot avoid dew formation on fruits, which, due to their thermal inertia, remain below the dew point temperature during the morning hours.

Thermal storage in the soil could mitigate day/night fluctuations, lengthen the growing season and increase productivity (Vanthoor et al., 2009). Mulching is the simplest way to increase greenhouse thermal inertia. Bonachela et al. (2012) observed a positive effect on soil heat flux and ground net radiation using black mulch, although the effect was stronger in root temperature than air temperature.

Water-filled polyethylene sleeves represent a passive technique, and were proposed in the eighties. The water 
sleeves act as a solar collector, absorbing solar energy during the day and releasing heat at night. Particularly in the earliest stages of plant growth, increases in greenhouse air temperature of up to $3^{\circ} \mathrm{C}$ have been reported. A study conducted in Northern Greece (Ntinas et al., 2015) obtained a 10.8\% increase in tomato production as well as an increase in antioxidant capacity of fruit in a greenhouse with water sleeves. This positive result could be due to the lower air temperature in the greenhouse with water sleeves during day-time, since during the day, part of the solar energy entering the greenhouse was used to heat the water sleeves. Previous studies reported lower levels of antioxidant compounds in tomato as the daily temperature increased (Riga et al., 2008).

Thermal screens, semi-closed greenhouses and increased thermal inertia produce limited (but important) improvements in the greenhouse night-time climate, and the coupling of such approaches may show interesting synergies. When passive techniques are used together, the greenhouse climate can be close to that of an active optimal greenhouse, but without using direct energy for heating.

\section{Crops and cultivation techniques}

\section{Vegetables crops}

Cucurbitaceae and Solanaceae are the predominant species in cold greenhouses, because they are widely consumed and comparatively well adapted to the unsteady climatic conditions. This situation normally results in monoculture and therefore there is a need for crop diversification. This could be enhanced through intraspecific genetic diversity, the cultivation of new, alternative crops, the cultivation of mixed crops and crop rotation (Tüzel and Oztekin, 2017). The most significant example of diversification through intraspecific genetic diversity concerns the tomato. In a well-provisioned market it is possible to find a wide range of tomato types, with diverse colours at ripening; some of them are new cultivars resembling old heirloom varieties (Tüzel and Oztekin, 2017). This diversification is also possible to find in many other cultivated greenhouse-grown vegetables. Thus, growers produce large varieties of pepper, eggplants of different sizes, shapes and colours, different types of melon, summer squash of different colours and shapes (whose flowers can be sold), seedless and small sized watermelon, short, medium and long cucumber types, yellow and variegated green bean cultivars, lettuces of attractive colours, textures and shapes and so on. Special mention should be made of miniaturisation, e.g., miniature vegetables. Besides well-known small tomatoes, snack sweet peppers and cucumbers (sweeter versions of their larger fruits) are a healthy alternative to sweet or savoury snacks. The distribution of these snack vegetables though refrigerated "healthy vending" machines is already a fact and promises to spread. In addition, as consumers are looking for softer textures in prepared salad mixes, baby-sized leafy vegetables have been one of the most promising fresh-cut developments. Finally, organic vegetable production is another way to increase crop diversification.

Finding new crops is not easy, although a large set of wild-growing species used in traditional Mediterranean dishes deserves more attention (Molina et al., 2016). The present tendency towards the recovery of food traditions and the need for product diversification may also offer opportunities for new crop domestication (Egea-Gilabert et al., 2013). In this last respect, some species which used to be cultivated and which have fallen out of fashion are being reintroduced.

Of special interest is the importance that brands are tak- ing in some markets. This usually involves closed framework agreements between a seed company, which offers a special product, and vegetable producers or traders, who can produce it exclusively, normally guaranteeing a high quality. Some of the most known cases are Kumato and Monterosa tomatoes, Fashion seedless watermelon, Sweet Palermo pepper, etc. Furthermore, in the case of melon, some brands were established in Spain some decades ago, usually offering a high quality toad skin melon. These brands belong to agricultural companies, which choose the cultivar and impose production techniques to ensure a good taste and sweetness of the product all year round.

\section{Berries and fruit tree crops}

Among the most notable aspects of species grown in protected cultivation in recent decades has been the incorporation of berries and fruit tree crops, in some cases due to the low profitability of certain vegetable crops, and in others, as a way of diversifying production and consequently reducing commercial risks. For example, in SW Spain, the cultivation of berries, such as raspberry, blueberry and blackberry, has increased in recent years at the expense of strawberry cultivation, which reflects a commitment to crop diversification. The cultivation of fruit crops in the greenhouses aims to extend their production to other areas, increase yield and quality and modify their growth cycle. Particularly, the cultivation of stone fruit trees has some additional advantages, since early production increases the possibility of export (Tüzel and Oztekin, 2015). In this case, crops are grown in the open air until their chilling requirements have been satisfied and then are covered by a cladding material, bringing forward their yield by some weeks. In other species with chilling requirements such as berries, these requirements are normally satisfied in the nursery, storing plant material at low temperature or growing the seedlings in cool places. In addition, some sub-tropical and tropical fruit trees (mango, papaya, pitaya, etc.) are now grown in the greenhouse, shortening their unproductive period, bringing forward their production and increasing the number of harvests. In greenhouses, some fruit trees are cultivated inside screenhouses or under horizontal screens. Films and nets to match specific requirements are increasingly used, particularly for improving effects on vegetative growth or fruit production. In this last respect, designing innovative covering materials, with specific radiometric properties to meet the requirements of growers, is increasingly necessary (Schettini et al., 2011).

\section{Floricultural and ornamental crops}

This sector is very diverse and includes the production of several crops. In recent years, cut flower production in protected cultivation has gradually increased in importance in many countries. Among the cut flowers, carnation, rose and chrysanthemum are the more widely grown crops, followed by gerbera, orchids, lilies, etc. Ornamental crops have also increased in recent years, particularly in developed countries; in this case, at the expense of reducing the area dedicated to cut flower cultivation. The optimal growing conditions presented by subtropical or tropical regions for cut flower cultivation, their low production costs and progress in postharvest techniques have also contributed to such diversification. Ornamental shrubs, bedding and balcony plants, Cacti and other succulent species, and indoor plants are the most commonly grown crops. 


\section{Grafting}

Grafting is largely used in Cucurbitaceae and Solanaceae species and is rapidly spreading and expanding all over the world. This technique produces plants that are more vigorous, the initial objective being protection against soil-borne diseases and soil fatigue provoked by successive cropping (Lee et al., 2010). Accordingly, the use of grafted plants permits some cultivars to be grown in non-disinfected soils following the banning of methyl-bromide as fumigant (LópezMarín et al., 2013). The purpose of grafting also has been greatly expanded to include various types of stress tolerance, increasing the yield and duration of crops and enhancing crop quality. Nowadays, rootstock breeding for vegetable crops includes other desirable traits such as compatibility with the scion, increased productivity and quality under stressful environments and improved use of soil, water and fertilizer resources (López-Marín et al., 2017). Accordingly, grafting is frequently used as an alternative to breeding in horticultural crops since suitable and compatible rootstocks can improve plant performance by increasing both nutrient uptake and utilization efficiency (Martínez-Andujar, 2017). Finally, the use of grafted plants can affect product quality, an aspect recently reviewed by Kyriacou et al. (2017) who provided an updated critical review of scientific advances.

\section{Fruit-setting}

The yield of most fruit-bearing vegetables depends on the success of fruit set, which is linked to pollination, particularly in a greenhouse. Certain insects are increasingly used to improve fruit setting, thus reducing the practice of chemical sprays, which are commonly used to ensure the fruiting of different crops. The limited air movement in the greenhouse and the temperature and humidity conditions, which in some periods do not allow adequate pollen production and viability, encourage the use of insects for pollination purposes. Indeed, in tomato, melon, watermelon, summer squash, mango and berries, this is already a widely used technique because of the reduced cost of insect pollinators compared to other techniques to improve fructification. Nevertheless, there is a continuing need for inducing parthenocarpy in vegetable crop plants, which is a highly desirable trait (Dhatt and Kaur, 2016). Currently, most commercial cucumber, banana and pineapple cultivars grown are parthenocarpic. Other vegetables species, such as tomato, sweet pepper, eggplant and summer squash, also include parthenocarpic cultivars, although their commercial use is not extensive. In addition, triploid cultivars are widely used for seedless watermelon production (Sarria, 2017), although in this case a diploid polliniser cultivar is also needed.

\section{Water and nutrient management}

\section{Water quality and management}

Water quality is critical to successful horticulture production in the greenhouse (De Pascale et al., 2013). Knowledge of available water quality allows water treatments to be planned, thus avoiding yield limitations associated with poor plant growth, staining, clogged watering pipes and other undesirable effects. Under commercial conditions, irrigation water comes from a number of different sources and therefore the intrinsic quality varies. Although it is not possible to indicate a standard analysis type for every condition, analytical testing should be regularly performed to avoid losses associated with the variations in water composition that sometimes occur. Furthermore, daily checking the $\mathrm{pH}$ and $\mathrm{EC}$ of the water circulating in the greenhouse is recommended in order to intervene promptly in the case of unexpected changes in the contents of salts dissolved in the irrigation water. In Mediterranean coastal areas salty ions build up over time because of high temperatures and evapotranspiration, poor water quality and the interaction of seawater with irrigation water; leading to increases in water salinity. Accordingly, in the longer term, it will be necessary to improve water quality, which can be achieved by water desalination, $\mathrm{pH}$ correction, acidification, the addition of bicarbonates or filtration (De Pascale et al., 2011).

Once quality features for allowing plant cultivation are set, sustainable irrigation management practices have to be addressed in order to preserve water sources, improve yield and reduce costs. Achieving high water use efficiency in greenhouse production is possible through optimal control of both cropping practices and environmental parameters (De Pascale et al., 2011). Among irrigation systems, the highest efficiencies are associated with micro-irrigation, e.g., by operating a slow and regular application of water operated at low pressures ( $<2$ bars) directly to the root zone. Micro-irrigation is operated through a network of valves, pipes, tubing and emitters, and special care should be devoted to avoid clogging of the nozzles (e.g., by adding a filter upstream in the distribution line or rinsing the system with chlorine, nitric of phosphoric acid) (De Pascale et al., 2013). Irrigation scheduling determines the amount of water applied to the crop (i.e., irrigation dose) and the timing of application (i.e., irrigation frequency). To improve irrigation scheduling, specific care should be devoted to the determination of both irrigation dose and frequency, taking into account soil or substrate hydraulic properties, crop species, water quality and irrigation system, which determine the depletion (\%) of the available water allowable in the root zone and the scheduling coefficient. To translate into practice, these calculations require the direct assessment of crop evapotranspiration (ET ${ }_{c}$ ) or the direct measurement of the moisture content in the growing medium with tensiometers or capacitance sensors. In recent years, innovation in soil moisture sensors has led to the diffusion of professional decision support systems (DSS) able to ensure optimal irrigation efficiency (e.g., Passam et al., 2001; Goumopoulos, 2012). Although the availability of cheap, easy-to-use commercial applications is still limited, useful protocols are available for guiding growers toward efficient greenhouse water management. Researches have addressed how sensors should be positioned, their distribution within the rhizosphere, and at different depths and lateral distances in order to control the wetting bulbs resulting from drip irrigation (Pardossi et al., 2009).

Specific considerations need to be made when planning irrigation for soilless culture; in this case automatically controlled irrigation systems are essential. These may be controlled through the inclusion of affordable and reliable tools - such as weighing gutter or tray systems - for the precise determination of $\mathrm{ET}_{\mathrm{c}}$ (Orgaz et al., 2005). Furthermore, the daily control of the $\mathrm{EC}$ and $\mathrm{pH}$ of drainage water and monthly monitoring of the same variables in the substrate are recommended, especially when poor-quality irrigation water is used (De Pascale et al., 2013). Finally, for hydroponic production, a scheduling coefficient of no more than 1.5 (Irrigation/ET $/ \mathrm{T}_{\mathrm{c}}$ ) should be maintained, thus providing a 33\% drain fraction.

\section{Soil fertility and plant nutrition}

Providing general recommendations concerning fertilizer requirements is a difficult task, since plant needs are 
affected by cropping systems and environmental conditions. Nevertheless, some general rules apply. Therefore fertilizer recommendation systems need to estimate this input (Epstein and Bloom, 2005). The application of nitrogen needs special care in order to optimize production and reduce losses to the environment (Soto el al., 2015). Optimal fertilizer management ensures unrestricted growth and a yield that is close to the maximum potential, while minimizing losses to the environment. Similarly, vegetable quality is at its best when fertilizer supply matches crop requirements throughout the growing season. Estimating the crop's nutrient requirement is very important for both economic and environmental reasons (Gianquinto et al., 2013).

Nutritional imbalances can be prevented by accurate monitoring of the crop mineral status. This, traditionally, is either performed visually in the crop or by means of soil analyses. However, although general recommendations suggest repeating chemical tests during the growing season (analysing the mineral composition of the soil but also, occasionally, of leaf tissues, growing medium and nutrient solution), these analyses are generally expensive and time consuming. Consequently, their replication during the crop season is still rare in commercial vegetable crop production. Nevertheless, recent research suggests that, for soil crops at least, petiole sap $\left(\mathrm{NO}_{3}^{-}-\mathrm{N}\right)$ is the most useful because of its sensitivity to crop $\mathrm{N}$ status and because it can be rapidly analysed on the farm (Peña-Fleitas et al., 2015). Real-time estimation of growth - and therefore of nutrient uptake - may be feasible through monitoring crop water uptake or plant transpiration.

Among recent innovations, a blended strategy combining modelling and monitoring approaches is growing in importance. Crop monitoring tools are increasingly used for rapidly obtaining indications of the actual nutrient status of the plant. Collected data are then transformed (either directly by the tool or by the operator) into vegetation indices (VIs). In the last decade, research has repeatedly addressed the application of optical tools for proper nitrogen management, for instance, in tomato (Gianquinto et al., 2011; Granados et al., 2013), melon (Gianquinto et al., 2009; Gallardo et al., 2011; Padilla et al., 2014), and cucumber (Padilla et al., 2017).

\section{Soilless culture}

Soilless culture refers to the cultivation of plants in soilless systems in which plant roots grow either in growing media in bags, containers or troughs as "substrate culture", or directly in nutrient solution. known as "water culture" or "hydroponics", including deepwater and deepflow culture, nutrient film technique (NFT), aeroponic, floating systems (Raviv and Lieth, 2007; Savvas et al., 2013; Popsimonova et al., 2016) or the more recent so-called New Growing System (NGS) (Selma et al., 2012).

In recent decades, the adoption of nutrient solutions for the optimization of crop nutrition has followed an increasing trend also in the Mediterranean (Muñoz et al., 2008), while cultivation in substrates has been characterized by a shift from open- to closed-cycle cultivation systems, involving reuse of the drainage solution, resulting in improved water and fertilizer use (Pardossi et al., 2006). Accordingly, closed systems can substantially reduce the pollution of water resources by nitrates and phosphates present in fertigation effluents, and contribute to an appreciable reduction in water and fertilizer consumption (Savvas, 2002). Switching over to closed cultivation systems has provided satisfactory evidences concerning yield and quality preservation, although special care needs to be devoted to avoiding high salt concentrations building up in the recycled nutrient solution, which may occur due to the entrance of salt ions and water at higher ratios (concentrations in the irrigation water) than the corresponding ion to-water uptake ratios (Thompson et al., 2007; Sonneveld and Voogt, 2009). Furthermore, the reuse of nutrient solution effluents may be associated with the risk of disease spreading via the recycled leachate, so that solution disinfection systems need to be installed (Chekli et al., 2017). In practice, recirculating nutrient solutions are generally disinfected by chemical treatment and UV radiation but are renewed from time to time (Wohanka, 2002; Possimonova et al., 2016).

The main advantages of soilless culture are the absence of soil-borne pathogens, safe and environmentally friendly alternative to soil disinfection, the saving of water and nutrient supplies, higher yields and quality, earlier harvests, the avoidance of soil tillage and preparation. However, higher installation costs and the technical skills and expertise required often constrain the diffusion of soilless horticulture in countries bordering the Mediterranean Basin (Raviv and Lieth, 2007; Gul, 2013; Savvas et al., 2013).

Soilless culture can be carried out in greenhouses located in favourable climatic conditions without any additional heating. However, in the last decade soilless cultivation has spread to areas where geothermal energy is available, e.g., Turkey, where it has been adopted in high-tech, wellequipped greenhouses (Gul, 2013; Tüzel and Oztekin, 2016). In recent years, production practices are increasingly carried out with machines as an "unmanned working model" in some soilless greenhouses.

Cultivation involving perlite, rockwool and cocopeat in containers, bags or slabs is a growing trend in vegetable production. Water culture has not been very common but recently the production of new crops, such as leafy vegetables (lettuce, rocket, spinach, lamb's lettuce, watercress, etc.) and herbs (parsley, basil, oregano, thyme, dill, etc.) in NFT, aeroponics and floating, which allows more plants per unit area and cleaner crops, has started to increase. Recently, too, "vertical farming systems" in tower shapes with aeroponic methods have started to be applied. This system provides 10 times more plants per unit area, a 50\% reduction in the harvest period, water and fertilizer savings, clean production and all year round production. In recent years, there has also been increased interest in growing strawberry and leafy vegetables by substrate culture especially in "A-shape" or "multy-storey" systems. Finally, aquaponics in soilless cultivation is little used in Mediterranean countries.

\section{Environmental issues in protected cultivation}

\section{Environmental impact of greenhouse production}

Despite using resources more efficiently, greenhouse production is often perceived as an artificial process, characterized by the low nutritional quality of its product and the heavy use of chemical inputs (Muñoz et al., 2008).

In order to improve the systems involved, the principles of cleaner production also need to be applied to greenhouses. The five main components of cleaner production are related to conserving raw materials, water and energy, eliminating toxic and dangerous raw materials, and reducing the quantity and toxicity of all emissions and wastes at source during the production process (Antón and Muñoz, 2013).

For unheated greenhouses, Antón et al. (2005) evaluated 
tomato production under a Mediterranean greenhouse, identifying the structure of the greenhouse, fertilizers, auxiliary equipment and waste as the most impacting points. For protected crops, structural components may account for nearly $30 \%$ of environmental impact categories such as resource depletion and global warming. Following this work, Antón et al. (2014) developed equations to provide an easy way to calculate the quantity of materials used to make greenhouses of different dimensions, thus resulting in more accurate calculation of the impacts of greenhouse production systems.

As regards the environment, tomato production in a heated greenhouse in the north of Italy implies an energy consumption of $95.5 \mathrm{MJ}$ eq $\mathrm{kg}^{-1}$ of tomato (Almeida et al., 2014), compared with 1-4 MJ eq $\mathrm{kg}^{-1}$ of tomato in unheated greenhouses. Heating systems represent one of the fundamental reasons why the environmental impact of production in France is greater than that of production in greenhouse without heating in Morocco, including the transport of the produce to France (Payen et al., 2015).

In terms of fertilizer use, Muñoz et al. (2008) demonstrated that the $\mathrm{N}$ concentration in the nutrient solution can be reduced without affecting production in a soilless tomato crop grown in a Mediterranean greenhouse. This reduction implies a decrease of $70 \%$ of the nitrogen leaving the system through leaching and a $60 \%$ decrease in the potential impact of eutrophication, and $50 \%$ decrease in the potential impact of climate change. In addition, closed or re-circulating hydroponic systems can significantly reduce fertilizer run-off and reduce the environmental impact (Antón et al., 2005). Nevertheless, closed systems need greater investment in installations and crop control. So, their economic viability is a question of debate in Southern Europe.

An alternative way to reduce fertilizer use and, hence, decrease the pollutant potential of leachates in soilless crops, is to collect and reuse lixiviates for a second soil crop in greenhouse or open air; in this way, a reduction in emissions to water of up to $50 \%$ can be achieved, and any impact on global warming is lessened (Muñoz et al., 2012). Besides, in a recent study, the reuse of lixiviates for a second crop in the open air allowed a sequence of outdoor crops to be fertigated without having to add more water and fertilizers than those already contained in the leachates (Muñoz et al., 2017). Related to the emissions associated with soilless crops, recent studies show that for lettuce crops, the estimated emissions are twice the level of real emissions, which would lead to an overestimation of the impact of more than $6 \%$ (Llorach et al., 2017). Martínez-Blanco et al. (2011) concluded that the replacement of a fraction of the mineral fertilizer dosage with compost would be a good agronomical and environmental solution for greenhouse tomato soil production.

Finally, to evaluate the impact of residues generated in greenhouse production, Antón et al. (2005) revealed that source segregation followed by the composting of biodegradable matter was the best way of managing waste to improve impact assessment. The segregation of non-yield biomass and its composting reduced the environmental burden for most of the impact categories considered. In addition, one of the environmental problems associated with this system of production, especially for soil crops in unheated greenhouses, is the large amount of plastics used - hence the importance of the proper management of this waste in a sustainable way (Antón et al., 2005). Among the solutions to this problem in Southern Spain is the recycling of such waste to produce other plastic commodities, such as rubbish bags, pots, boxes for handling vegetables, etc. (mechanical recycling) and the valorisation of waste as energy source, which is achieved by burning the plastic waste in a nearby power plant for the generation of electricity (Montero et al., 2014). The use of satellite data for geo-referencing agricultural plastic wastes would allow waste managers to use this information to decide the position of collection centres and waste route maps (Lanorte et al., 2017).

\section{Integrated pest management}

Pests and diseases in protected crops are changing as fast as the new cultivation methods are introduced, so new control measures are required. The high value of greenhouse crops justifies the use of expensive control measures, and is normally accepted by growers.

Severalyears ago, managementstrategies changed toward integrated pest management (IPM) as a way of reconciling the control of harmful agents and sustainability, bearing in mind consumer health and safety and the protection and respect of the environment. Many governments are implementing national plans aimed at reducing the pesticide use (Hillocks, 2012).

The most innovative techniques for the management of pests and diseases in protected crops can be divided into preventive and curative, as shown below. Many of these techniques, which are alternatives to chemical control, have only a partial effect on pests and diseases and must be combined with other means to provide effective control.

\section{Preventive measures: limiting the invasion of pests and pathogens}

- Legislation forbidding or restricting the importation of particular plants from infected areas. That is extremely important in order to prevent or diminish the risk of exotic pest species becoming endemic (Hanafi, 2013).

- Strategies like purchasing healthy seeds, or eliminating the sources of primary inoculum within and close to the crop.

The use of insect-proof nets, on roof vents or covering the greenhouses to prevent infestation by establishing a physical barrier between the invading pest and the crop. The mesh size should exclude the insect and at the same time allow airflow so that achieving this balance is not easy. Among the main pests that can be prevented are whiteflies, aphids and miners. In addition, there are anti-insect meshes that can incorporate insecticides or repellents, so they reduce the passage of insects to the interior while allowing better ventilation. These barriers have been shown to be effective for the control of aphid-transmitted viruses (Dader et al., 2014).

Coloured plastics, besides constituting a physical barrier, modify the behaviour of the insect by altering its vision. In addition, coloured meshes can be used to completely cover macro structures, micro (low) tunnels and greenhouses, resulting in a double mechanism of action on the insect.

Solarization can be used to decrease the amount of inoculum, thus affecting the viability of species like Pythium spp. and Phytophthora spp. Also, the use of buried manure and its variants (biofumigation) is regarded as an alternative to the use of methyl bromide. The combination of biofumigation with solarization (biosolarization) in areas of high insolation has obtained similar result to methyl bromide (Guerrero et al., 2008), besides correcting the fatigue of the soil caused by monocultures. 


\section{Curative measures: limiting pests and pathogens} development on plants during cultivation

- Chromotropic traps for monitoring pests are quite useful with small populations but are less effective in the case of massive infestations. The same applies to pheromone diffusers. The mass trapping method, using semiochemicals, is used, for lepidoptera and thrips, providing an environmentally friendly control method; however, its full potential for pest management has not been realized and further research into and development of this technology is necessary (El Sayed et al., 2006).

- The use of resistant plants to control the different phytosanitary problems. Sometimes this is the only method of control possible (virus, vascular pathogens), since other options are not available or are very expensive. The availability of resistant commercial varieties is wide and is continuously growing in the case of the main vegetable crops, not only for combatting diseases, but also pests. However, pests and pathogens may overcome genetic resistance, especially when one or few genes are involved (vertical resistance). The identification and regular introduction of new resistance genes, the combination of a maximum number of resistance genes, and the introduction of partial resistance are new strategies proposed for enhancing plant genetic resistance (Dogimont et al., 2010; Pink, 2002).

- A noteworthy example of exploitation is the tomato $M i-1$ gene which, in addition to providing resistance to several species of nematodes (Meloidogyne spp.), also confers resistance to Macrosiphon euphorbiae, Bemisia tabaci, and some other pests. Nowadays, there are several commercially available tomato and pepper cultivars that are resistant to Meloidogyne spp. (Kiewnick et al., 2009). Resistant plants pepper to oidium (Leveilula taurica) are beginning to reach the market, as well as a cross-protected product against sweet cucumber mosaic virus (PepMV). Biotechnology, transforming plants with genes encoding for antibodies directed against pathogens, opens up huge opportunities for the future of plant resistance.

- The use of grafted plants to control Fusarium oxysporium in watermelon and Verticillium dahliae in eggplant is quite usual (Lee et al., 2010). In addition, in some areas, grafted plants are used to control Phytophthora spp. and Meloidogyne spp. in sweet pepper (López-Marín et al., 2017) and Fusarium spp. in tomato, respectively.

- As fertilization affects plant-pathogen as well as plant-pest relationships, which may be promoted or inhibited, the optimal nutritional status of plants increases their resistance to the attack of pests and diseases. In addition, irrigation must be correctly calculated, since an excess of humidity, besides favouring root asphyxia, increases the attack of soil diseases (damping off, root rot, nematodes, etc.).

- Biological control in greenhouses has been applied with success for many years. Acceptance of this method has been remarkably fast because of the resistance to pesticides that several key pests have developed (Hanafi, 2008, 2013), and the fact that the number of pesticides available has decreased.

- The introduction of banker plants into a crop is a preventive and long-term significant example for aphis control (Barriere et al., 2013). Besides, biological control agents such as Conipthyrium minitans and Thrichoderma spp. can be introduced in soil to manage soil-borne pathogens.
- The main pests in protected crops can also be controlled by the mass release of beneficial organisms as a curative technique. However, for the presence of secondary pests, there is no biological solution available yet, so that more effort is needed in the search for natural enemies for the new pests.

The usefulness of hedges, green corridors and vegetation islands around greenhouses should not be underestimated for enhancing the presence of natural enemies that can curb the dispersal of pests. The same plant species can be introduced in the greenhouse for the same purpose. Moreover, methods such as mixed cropping, multiple and intercropping and trap cropping are a way to increase biodiversity or increase biological control in organic farming. Knowledge of the induction of volatile emission by plants, as an immediate response to pest attacks (Herbivore-induced plant volatiles, HIPVs), has also opened up a new field of research for enhancing the effectiveness of host plant resistance and biological control for integrated pest management (War et al., 2011).

- With regard to the application of pesticides, it is essential for the future of IPM to fully understand their compatibility with natural enemies and pollinators (Bielza and Lacasa, 2014). Some techniques, such as applying treatments via an irrigation system, using baits that differentially attract pests and beneficial insects, applying treatments focused on some part of the plant, can help. In addition, auxiliary populations that are more tolerant to pesticides could be established through classic breeding systems, or through genetic engineering.

\section{Conclusions}

The recent developments in greenhouse production in Mediterranean climates which have been presented in this review point to the high degree of innovation and research carried out within the industry and research centres in recent years with the aim of achieving more sustainable and competitive production. Climate change will almost certainly bring more problems that will need to be taken into account in the near future, and will lead to modifications in most of the current strategies of production, particularly those related to rising temperatures and water shortages. Thus, new effective tools to tackle this new situation will be needed, without affecting the competitiveness of the horticultural crops value chain.

\section{References}

Adelhafidi, A., Babaghayou, I.M., Chabira, S.F., and Sebaa, M. (2015). Impact of solar radiation effects on the physicochemical properties of polyethylene (PE) plastic film. Procedia Soc. Behav. Sci. 195, 22102217. https://doi.org/10.1016/j.sbspro.2015.06.302.

Almeida, J., Achten, W.M.J., Verbist, B., Heuts, R.F., Schrevens, E., and Muys, B. (2014). Carbon and water footprints and energy use of greenhouse tomato production in Northern Italy. J. Ind. Ecol. 18, 898-908. https://doi.org/10.1111/jiec.12169.

Antón, A., Muñoz, P., Castells, F., Montero, J.I., and Soliva, M. (2005). Improving waste management in protected horticulture. Agron. Sustain. Dev. 25, 447-453. https://doi.org/10.1051/agro:2005045.

Antón, A., and Muñoz, P. (2013). Integrated preventive environmental strategy in greenhouse production. In Good Agricultural Practices for Greenhouse Vegetable Crops. Principles for Mediterranean Climate Areas, W. Baudoin, N. Castilla, and M. Qaryouti, eds. (Rome, Italy: FAO Publications), p. 565-579. 
Antón, A., Torrellas, M., Raya, V., and Montero, J.I. (2014). Modelling the amount of materials to improve inventory datasets of greenhouse infrastructures. Int. J. Life Cycle Assess. 19, 29-41. https://doi. org/10.1007/s11367-013-0607-z.

Baille, A., López, J.C., Bonachela, S., González-Real, M.M., and Montero, J.I. (2006). Night energy balance in a heated low-cost plastic greenhouse. Agric. For. Meteorol. 137, 107-118. https://doi. org/10.1016/j.agrformet.2006.03.008.

Baille, A. (2001). Trends in greenhouse technology for improved climate control in mild winter climates. Acta Hortic. 559, 161-168. https://doi.org/10.17660/ActaHortic.2001.559.23.

Barrière, V., Lecompte, F., Nicot, P.C., Maisonneuve, B., Tchamitchigan, M., and Lescourret, F. (2013). Lettuce cropping with less pesticide. A review. Agron. Sustain. Dev. 34(1), 175-198. https://doi. org/10.1007/s13593-013-0158-5.

Baeza, E.J. (2007). Optimización del diseño de los sistemas de ventilación en invernaderos tipo parral. Ph.D. thesis. (Almería, Spain: Universidad de Almería).

Baeza, E.J., Pérez-Parra, J., Montero, J.I., Bailey, B., Lopez, J.C., and Gazquez, J.C. (2009). Analysis of the role of sidewall vents on buoyancy-driven natural ventilation in parral-type greenhouses with and without insect screens using computational fluid dynamics. Biosyst. Engin. 104, 86-96. https://doi.org/10.1016/j. biosystemseng.2009.04.008.

Baeza, E., and López, J.C. (2012). Light transmission through greenhouse covers. Acta Hortic. 956, 425-440. https://doi. org/10.17660/ActaHortic.2012.956.50.

Baeza, E.J., and Kacira, M. (2017). Greenhouse technology for cultivation in arid and semi-arid regions. Acta Hortic. 1170, 17-30. https://doi.org/10.17660/ActaHortic.2017.1170.2.

Baptista, F. (2007). Modelling the climate in unheated tomato greenhouses and predicting Botrytis cinerea infection. Ph.D. thesis (Évora, Portugal: Universidade de Évora)

Bartzanas, T., and Kittas, C. (2001). Optimisation of greenhouses ventilation performance with computational fluid dynamics. In $2^{\text {nd }}$ Southeastern Europe Fluent Users Group Meeting, Bucharest Romania (Thessaloniki, Greece: Simtec Eds.) (CD-ROM).

Bartzanas, T., Boulard, T., and Kittas, C. (2004). Effect of vent arrangement on windward ventilation of a tunnel greenhouse. Biosyst. Engin. 88, 479-490. https://doi.org/10.1016/j. biosystemseng.2003.10.006.

Bielza, P., and Lacasa, A. (2014). The toxicity of phytosanitaries on pollinations insects and on useful arthropods. In Organisms for the Control of Pathogens in Protected Crops. Cultural Practices for Sustainable Agriculture, J.C. Tello, and F. Camacho, eds. (Almería, Spain: Fundación Cajamar), p. 371-390.

Bonachela, S., Granados, M.R., López, J.C., Hernández, J., Magán, J.J., Baeza, E.J., and Baille, A. (2012). How plastic mulches affect the thermal and radiative microclimate in an unheated lowcost greenhouse. Agric. For. Meteorol. 152, 65-72. https://doi. org/10.1016/j.agrformet.2011.09.006.

Boulard, T., and Fatnassi, H. (2005). Greenhouse aeration and climate optimization based on CFD studies. Plasticulture 124, 38-57.

Bournet, P., and Boulard, T. (2010). Effect of ventilator configuration on the distributed climate of greenhouses: A review of experimental and CFD studies. Comput. Electron. Agric. 7(2), 195-217. https:// doi.org/10.1016/j.compag.2010.08.007.

Briassoulis, D., and Schettini, E. (2003). Analysis and design of lowdensity polyethylene greenhouse films. Biosyst. Engin. 84(3), 303314. https://doi.org/10.1016/S1537-5110(02)00241-6.
Castilla, N. (2013). Greenhouse Technology and Management, $2^{\text {nd }}$ edn. (Oxfordshire: Cab International). https://doi.org/10.1079/ 9781780641034.0000

Chekli, L., Kim, J.E., El Saliby, I., Kim, Y., Phuntsho, S., Li, S., Ghaffour, N. Leiknes, T., and Shon, H.K. (2017). Fertilizer drawn forward osmosis process for sustainable water reuse to grow hydroponic lettuce using commercial nutrient solution. Sep. Purif. Technol. 181, 18-28. https://doi.org/10.1016/j.seppur.2017.03.008.

Dáder, B., Legarrea, S., Moreno, A., Ambros, C.M., Fereres, A., Skovmand, O., Bosselmann, R., and Viñuela, E. (2014). Insecticidetreated nets as a new approach to control vegetable pest in protected crops. Acta Hortic. 1015, 103-111. https://doi.org/10.17660/ ActaHortic.2014.1015.11.

De Pascale, S., Della Costa, L., Vallone, S., Barbieri, G., and Maggio, A. (2011). Increasing water use efficiency in vegetable crop production: from plant to irrigation systems efficiency. HortTechnology 21,301-308.

De Pascale, S., Orsini, F., and Pardossi, A. (2013). Irrigation water quality for greenhouse horticulture. In Good Agricultural Practices for Greenhouse Vegetable Crops. Principles for Mediterranean Climate Areas, W. Baudoin, N. Castilla, and M. Qaryouti, eds. (Rome, Italy: FAO Publications), p. 169-204.

Dhatt, A.S., and Kaur, G. (2016). Parthenocarpy: A potential trait to exploit in vegetable crops: A review. Agric. Rev. 37(4), 300-308. https://doi.org/10.18805/ag.v37i4.6460.

Dogimont, C., Bendahmane, A., Chovelon, V., and Boissot, N. (2010). Host plant resistance to aphids in cultivated crops genetic and molecular bases, and interactions with aphid populations. C.R. Biol. 333 (6-7), 566-573. https://doi.org/10.1016/j.crvi.2010.04.003.

Egea-Gilabert, C., Niñirola, D., Conesa, E., Candela, M., and Fernández, J.A. (2013). Agronomical use as baby leaf salad of Silene vulgaris based on morphological, biochemical and molecular traits. Sci. Hortic. 152, 35-43. https://doi.org/10.1016/j.scienta.2013.01.018.

Elingsa, A., Dueck, T., Meinen, E., and Kempkes, F. (2012). Analysis of the effects of diffuse light on photosynthesis and crop production. Hortimodel 2012. Acta Hortic. 957, 45-52. https://doi. org/10.17660/ActaHortic.2012.957.4

El Mouedden, Y., Alghamedi, R., Nur-E-Alam, M., Vasiliev, M., and Alameh, K. (2012). Thin film coatings for solar and thermal radiation control prepared by physical vapour deposition. In High Capacity Optical Networks and Emerging/Enabling Technologies (HONET 2012) (Istanbul, Turkey: IEEE), p. 83-86. https://doi.org/10.1109/ HONET.2012.6421440.

El-Sayed, A.M., Suckling, D.M., Wearing, C.H., and Byers, J.A. (2006). Potential of mass trapping for long-term pest management and eradication of invasive species. J. Econ. Entomol. 99(5), 1550-1556. https://doi.org/10.1093/jee/99.5.1550.

Epstein, E., and Bloom, A.J. (2005). Mineral Nutrition of Plants: Principles and Perspectives. $2^{\text {nd }}$ edn. (Sunderland: Sinauer Associates, Inc., Publishers).

Espí, E., Salmerón, A., Fontecha, A., García, Y., and Real, A.I. (2006). Plastic films for agricultural applications. J. Plastic Film \& Sheeting 22, 85-102. https://doi.org/10.1177/8756087906064220.

Gallardo, M., Giménez, C., Martínez-Gaitán, C., Stöcklec, C., Thompson, R.B., and Granados, M.R. (2011). Evaluation of the VegSyst model with muskmelon to simulate crop growth, nitrogen uptake and evapotranspiration. Agric. Water Mgt. 101, 107-117. https://doi. org/10.1016/j.agwat.2011.09.008

García, M.L., Medrano, E., Sánchez-Guerrero, M.C., and Lorenzo, P. (2011). Climatic effects of two cooling systems in greenhouses in the Mediterranean area: external mobile shading and fog system. Biosyst. Eng. 108(2), 133-143. https://doi.org/10.1016/j. biosystemseng.2010.11.006. 
Gbiorczyk, K. (2003). New test methods for evaluating the antifog effect of greenhouse films. Gartenbautechnische Informationen, Heft 58 (Hannover: Institut für Technik in Gartenbau und Landwirtschaft, Universität Hannover), 195 pp.

Giacomelli, G.A., Sase, S., Cramer, R., Hoogeboom, J., MacKenzie, A., Parbst, K., Scarascia-Mugnozza, G., Selina, P., Sharp, D.A., Voogt, J.O., Van Weel, P.A., and Mears, D. (2012). Greenhouse production systems for people. Acta Hortic. 927, 23-38. https://doi.org/10.17660/ ActaHortic.2012.927.1.

Gianquinto, G., Fecondini, M., Mezzetti, M., and Orsini, F. (2009). Steering nitrogen fertilization by means of portable chlorophyll meter reduces nitrogen input and improves quality of fertigated cantaloupe (Cucumis melo L. var. cantalupensis Naud.). J. Sci. Food Agric. 90, 482-493.

Gianquinto, G., Orsini, F., Fecondini, M., Mezzetti, M., Sambo, P., and Bona, S. (2011). A methodological approach for defining spectral indices for assessing tomato nitrogen status and yield. Eur. J. Agron. 35, 135-143. https://doi.org/10.1016/j.eja.2011.05.005.

Gianquinto, G., Muñoz, P., Pardossi, A., Ramazzotti, S., and Savvas, D. (2013).Soil fertility and plant nutrition. In Good Agricultural Practices for Greenhouse Vegetable Crops. Principles for Mediterranean Climate Areas, W. Baudoin, N. Castilla, and M. Qaryouti, eds. (Rome, Italy: FAO Publications), p. 205-269.

Gomez-Mataix, G., Montero, J.I., Raya, V., and Suay, R. (2013) Benchmark study of the distance between greenhouses and its effect on wind driven ventilation. Acta Hortic. 1008, 207-211. https://doi. org/10.17660/ActaHortic.2013.1008.27.

Goumopoulos, C. (2012). An autonomous wireless sensor/actuator network for precision irrigation in greenhouses. In Smart Sensing Technology for Agriculture and Environmental Monitoring, S. Mukhopadhyay, ed. (Berlin, Germany: Springer Berlin, Heidelberg), p. 1-20. https://doi.org/10.1007/978-3-642-27638-5_1.

Gbiorczyk, K., von Elsner, B., Sonneveld, P.J. and Bot, G.P.A. (2002). The effect of roof inclination on the condensation behavior of plastic films used as greenhouse covering materials. Acta Hortic. 633, 127136. https://doi.org/10.17660/ActaHortic.2004.633.15.

Granados, M.R., Thompson, R.B., Fernández, M.D., Martínez-Gaitán, C., and Gallardo, M. (2013). Prescriptive-corrective nitrogen and irrigation management of fertigated and drip-irrigated vegetable crops using modelling and monitoring approaches. Agric. Water Mgt. 119, 121-134. https://doi.org/10.1016/j.agwat.2012.12.014.

Gul, A. (2013). Progress in soilless cultivation in Turkey. Soil Water J. 2(2), 2257-2264.

Guerrero, M.M., Lacasa, C.M., Ros, C., Martínez, V., López, M.A. Martínez, M.A., Beltrán, C., Monserrat, A., and Fernández, P. (2008) Enmiendas orgánicas para biosolarización de suelos de invernaderos de pimiento. Actas de Hortic. 50, 83-88.

Hanafi, A. (2008). Integrated Production and Protection in Greenhouse Crops (GAP) (Beirut: Hanafi Abdelhaq).

Hanafi, A. (2013). Integrated pest management. In Good Agricultural Practices for Greenhouse Vegetable Crops. Principles for Mediterranean Climate Areas, W. Baudoin, N. Castilla, and M. Qaryouti, eds. (Rome, Italy: FAO Publications), p. 427-510.

Hemming, S., Mohammadkhani, V., and Dueck, T. (2008). Diffuse greenhouse covering materials - material technology, measurements and evaluation of optical properties. Acta Hortic. 797, 469-475. https://doi.org/10.17660/ActaHortic.2008.797.68.

Hernández, G. (2009). Valoración radiativa. microclimática y productiva de dos invernaderos con diferente geometría de cubierta (hemicircular y lineal simétrica a dos aguas). Ph.D. thesis (Almería, Spain: Universidad de Almería).
Heuvelink, E. (2005). Tomatoes. (Oxfordshire: Cab International). https://doi.org/10.1079/9780851993966.0000.

Hillocks, R.J. (2012). Farming with fewer pesticides: EU pesticide review and resulting challenges for UK agriculture. Crop Prot. 31, 85-93. https://doi.org/10.1016/j.cropro.2011.08.008.

Hong, S.W., Lee, I.B., Hwang, H.S., Seo, I.H., Bitog, J.P., Yoo, J.I., Kim, K.S., Lee, S.H., Kim, K.W., and Yoon, N.K. (2008). Numerical simulation of ventilation efficiencies of naturally ventilated multi-span greenhouses in Korea. Trans. ASABE 51(4), 1417-1432. https://doi. org/10.13031/2013.25235.

Kacira, M., Short, T.H., and Stowell, R. (1998). A CFD evaluation of naturally ventilated multi-span, sawtooth greenhouses. Transactions ASAE 41(3), 833-836. https://doi.org/10.13031/2013.17222.

Kacira, M., Sase, S., and Okushima, L. (2004). Effects of side vents and span numbers on wind-induced natural ventilation of a gothic multispan greenhouse. Japan Agric. Res. Quart. 38, 227-233. https://doi. org/10.6090/jarq.38.227.

Khandelwal, H., Debije, M.G., White, T.J., and Schenning, A.P.H.J. (2016). Electrically tunable infrared reflector with adjustable bandwidth broadening up to $1100 \mathrm{~nm}$. J. Mater. Chem. A, 4(16), 6064-6069. https://doi.org/10.1039/C6TA01647B.

Kiewnick, S., Dessimoz, M., and Franck, L. (2009). Effects of the $M i-1$ and the $N$ root-knot nematode-resistance gene on infection and reproduction of Meloidogyne enterolobii on tomato and pepper cultivars. J. Nematol. 41(2), 134-139.

Kyriacou, M.C, Rouphael, Y., Colla, G., Zrenner, R., and Schwarz, D. (2017). Vegetable grafting: the implications of a growing agronomic imperative for vegetable fruit quality and nutritive value. Front. Plant Sci. 8, 741. https://doi.org/10.3389/fpls.2017.00741.

Lanorte, A., De Santis, F., Nolè, G., Blanco, I., Loisi, R.V., Schettini, E., and Vox, G. (2017). Agricultural plastic waste spatial estimation by Landsat 8 satellite images. Comp. and Electron. in Agric. 141, 35-45. https://doi.org/10.1016/j.compag.2017.07.003.

Lee, J.M., Kubota, C., Tsao, S.J., Bie, Z., Hoyos Echevarria, P., Morra, L., and Oda, M. (2010). Current status of vegetable grafting: diffusion, grafting techniques, automation. Sci. Hortic. 127, 93-105. https:// doi.org/10.1016/j.scienta.2010.08.003.

López-Marín, J., González, A., Pérez-Alfocea, F., Egea-Gilabert, C., and Fernández, J.A. (2013). Grafting is an efficient alternative to shading screens to alleviate thermal stress in greenhouse-grown sweet pepper. Sci. Hortic. 149, 39-46. https://doi.org/10.1016/j. scienta.2012.02.034.

López-Marín, J., Gálvez, A., del Amor, F.M., Albacete, A., Fernández, J.A., Egea-Gilabert, C., and Pérez-Alfocea, F. (2017). Selecting vegetative/ generative/dwarfing rootstocks for improving fruit yield and quality in water stressed sweet peppers. Sci. Hortic. 214, 9-17. https://doi. org/10.1016/j.scienta.2016.11.012.

Llorach, P., Muñoz, P., Riera, M.R., Gabarrell, X., Rieradevall, J., Montero, J.I., and Villalba, G. (2017). $\mathrm{N}_{2} \mathrm{O}$ emissions from protected soilless crops for more precise food and urban agriculture life cycle assessments. J. Cleaner Prod. 149, 1118-1126. https://doi. org/10.1016/j.jclepro.2017.02.191.

Martínez-Andújar, C., Ruiz-Lozano, J.M., Dodd, I.C., Albacete, A., and Pérez-Alfocea, F. (2017). Hormonal and nutritional features in contrasting rootstock-mediated tomato growth under lowphosphorus nutrition. Front. Plant Sci. 8, 533. https://doi. org/10.3389/fpls.2017.00533.

Martínez-Blanco, J., Muñoz, P., Antón, A., and Rieradevall, J. (2011) Assessment of tomato Mediterranean production in open-field and standard multi-tunnel greenhouse, with compost or mineral fertilizers, from an agricultural and environmental standpoint. J. Clean Prod. 19(9-10), 985-997. https://doi.org/10.1016/j.jclepro.2010.11.018. 
Molina, M., Pardo-de-Santayana, M., and Tardío, J. (2016). Natural production and cultivation of Mediterranean wild edibles. In Mediterranean Wild Edible Plants, M.C. Sánchez-Mata, and J. Tardío, eds. (New York, USA: Springer Science+Business Media), p. 81-107. https://doi.org/10.1007/978-1-4939-3329-7_5.

Montero, J.I., Hunt, G.R., Kamaruddin, R., Antón, A., and Bailey, B.J. (2001). Effect of ventilator configuration on wind driven ventilation in a crop protection structure for the tropics. J. Agric. Engin. Res. 80(1), 99-107. https://doi.org/10.1006/jaer.2000.0694

Montero, J.I., Stanghellini, C., and Castilla, N. (2009). Greenhouse technology for sustainable production in mild winter climate areas: Trends and needs. Acta Hortic. 807, 33-44. https://doi. org/10.17660/ActaHortic.2009.807.1.

Montero, J.I., Muñoz P., Sánchez-Guerrero, M.C., Medrano, E., Piscia, D., and Lorenzo, P. (2013). Shading screens for the improvement of the night time climate of unheated greenhouses. Span. J. Agric. Res. 11(1), 32-46. https://doi.org/10.5424/sjar/2013111-411-11.

Montero, J.I., Teitel, M., and López, J.C. (2014). Developments in covering materials for intensive horticulture: technical properties and recycling opportunities. Acta Hortic. 1015, 269-280. https:// doi.org/10.17660/ActaHortic.2014.1015.30.

Muñoz, P., Antón, A., Paranjpe, A., Ariño, J., and Montero, J.I. (2008). High decrease in nitrate leaching by lower $\mathrm{N}$ input without reducing greenhouse tomato yield. Agron. Sustain. Dev. 28, 489-495. https:// doi.org/10.1051/agro:2008024.

Muñoz, P., Paranjpe, A., Montero, J.I., and Antón, A. (2012). Cascade crops: an alternative solution for increasing sustainability of greenhouse tomato crops in Mediterranean zone. Acta Hortic. 927, 801-806. https://doi.org/10.17660/ActaHortic.2012.927.99.

Muñoz, P., Flores, J.S., Antón, A., and Montero, J.I. (2017) Combination of greenhouse and open-field crop fertigation can increase sustainability of horticultural crops in the Mediterranean region. Acta Hortic. 1170, 627-634. https://doi.org/10.17660/ ActaHortic.2017.1170.78.

Norton, T., Sun, D.W., Grant, J., Fallon, R., and Dodd, V. (2007). Applications of computational fluid dynamics CFD in the modelling and design of ventilation systems in the agricultural industry: a review. Biores. Technol. 98, 2386-2414. https://doi.org/10.1016/j. biortech.2006.11.025.

Ntinas, G.K., Koukounaras, A., and Kotsopoulos, T. (2015). Effect of energy saving solar sleeves on characteristics of hydroponic tomatoes grown in a greenhouse. Sci. Hortic. 194, 126-133. https:// doi.org/10.1016/j.scienta.2015.08.013.

Ould Khaoua, S.A., Bournet, P.E., Migeon, C., Chassériaux, G., and Boulard, T. (2006). Analysis of greenhouse ventilation efficiency with CFD. Biosyst. Engin. 95(1), 83-98. https://doi.org/10.1016/j. biosystemseng.2006.05.004.

Orgaz, F., Fernández, M.D., Bonachela, S., Gallardo, M., and Fereres, E. (2005). Evapotranspiration of horticultural crops in an unheated plastic greenhouse. Agric. Water Mgt. 72, 81-96. https://doi. org/10.1016/j.agwat.2004.09.010.

Padilla, F.M., Peña-Fleitas, M.T., Gallardo, M., and Thompson, R.B. (2014). Evaluation of optical sensor measurements of canopy reflectance and of leaf flavonols and chlorophyll contents to assess crop nitrogen status of muskmelon. Eur. J. Agron. 58, 39-52. https:// doi.org/10.1016/j.eja.2014.04.006.

Padilla, F.M., Peña-Fleitas, M.T., Gallardo, M., and Thompson, R.B. (2017). Determination of sufficiency values of canopy reflectance vegetation indices for maximum growth and yield of cucumber. Eur. J. Agron. 84, 1-15. https://doi.org/10.1016/j.eja.2016.12.007.
Papadakis, G., Briassoulis, D., Scarascia Mugnozza, G., Vox, G. Feuilloley, P., and Stoffers, J.A. (2000). Radiometric and thermal properties of, and testing methods for, greenhouse covering materials. J. Agric. Engin. Res. 77(1), 7-38. https://doi.org/10.1006/ jaer.2000.0525

Papadopoulos, A.P., and Xiuming Hao (1997). Effects of three greenhouse cover materials on tomato growth, productivity, and energy use. Sci. Hortic. 70(2), 165-178. https://doi.org/10.1016/ S0304-4238(97)00054-X.

Pardossi, A., Malorgio, F., Incrocci, L., Carmassi, G., Maggini, R., Massa, F., and Tognoni, F. (2006). Simplified models for the water relations of soilless cultures: what they do or suggest for sustainable water in intensive horticulture. Acta Hortic. 718, 425-434. https://doi. org/10.17660/ActaHortic.2006.718.49.

Pardossi, A., Incrocci, L., Incrocci, G., Malorgio, F., Battista, P., Bacci, L., Rapi, B., Marzialetti, P., Hemming, J., and Balendonck, J. (2009). Root zone sensors for irrigation management in intensive agriculture. Sensors 9, 2809-2835. https://doi.org/10.3390/s90402809.

Passam, H.C., Sideridis, A.B., Yialouris, C.P., and Maliappis, M.T (2001). Improvement of vegetable quality and water and fertilizer utilization in low-tech greenhouses through a decision support management system. J. Veg. Crop Prod. 7(1), 69-82. https://doi. org/10.1300/J068v07n01_09.

Payen, S., Basset-Mens, C., and Perret, S. (2015). LCA of local and imported tomato: An energy and water trade-off. J. Cleaner Prod. 87, 139-148. https://doi.org/10.1016/j.jclepro.2014.10.007.

Peña-Fleitas, M.T., Gallardo, M., Thompson, R.B., Farneselli, M., and Padilla, F.M. (2015) Assessing crop N status of fertigated vegetable crops using plant and soil monitoring techniques. Ann. Appl. Biol. 167, 387-405. https://doi.org/10.1111/aab.12235.

Perez Parra, J., Baeza, E., Montero, J.I., and Bailey, B.J. (2004). Natural ventilation of parral greenhouses. Biosyst. Engin. 873, 355-366. https://doi.org/10.1016/j.biosystemseng.2003.12.004.

Pink, D.A.C. (2002). Strategies using genes for non-durable disease resistance. Euphytica 124(2), 227-236. https://doi. org/10.1023/A:1015638718242.

Piscia, D. (2012). Analysis of night-time climate in plastic-covered greenhouses. Ph.D. thesis (Spain: Universitat Politécnica de Catalunya).

Popsimonova, G., Benko, B., Karic, L., and Gruda, N. (2017). Production systems-integrated and organic production and soilless culture. In GAP for Greenhouse Vegetable Production in the SEE Countries: Principles for Sustainable Intensification of Smallholder Farms, W. Baudoin, S. De Pascale, N. Gruda, L. Urban, and J. Tany, eds. (Rome, Italy: FAO Publications), p. 207-216.

Raviv, M., and Lieth, J.H. (2007). Soilless Culture: Theory and Practice, $1^{\text {st }}$ edn. (Amsterdam: Elsevier Science).

Raya-Ramallo, V. (2014). Mejora de la productividad del cultivo de tomate para exportación en Canarias. Ph.D. thesis (San Cristóbal de La Laguna, Spain: Universidad de La Laguna).

Riga, P., Anza, M., and Garbisu, C. (2008). Tomato quality is more dependent on temperature than on photosynthetically active radiation. J. Sci. Food Agric. 88(1), 158-166. https://doi org/10.1002/jsfa.3065.

Sarria, E. (2017). Global challenges for the future of watermelon breeding. Acta Hortic. 1151, 5-8. https://doi.org/10.17660/ ActaHortic.2017.1151.2 
Savvas, D. (2002). Automated replenishment of recycled greenhouse effluents with individual nutrients in hydroponics by means of two alternative models. Biosyst. Eng. 83, 225-236. https://doi. org/10.1006/bioe.2002.0106.

Savvas, D., Gianquinto, G., Tüzel, Y., and Gruda, N. (2013). Soilless culture. In Good Agricultural Practices for Greenhouse Vegetable Crops. Principles for Mediterranean Climate Areas, W. Baudoin, N. Castilla, and M. Qaryouti, eds. (Rome, Italy: FAO Publications), p. 303-354.

Schettini, E., de Salvador, F.R., Scarascia-Mugnozza, G., and Vox, G. (2011). Radiometric properties of photoselective and photoluminescent greenhouse plastic films and their effects on peach and cherry tree growth. J. Hortic. Sci. Biotechnol. 86(1), 79-83. https://doi.org/10.1080/14620316.2011.11512729.

Schettini, E., and Vox, G. (2012). Effects of agrochemicals on the radiometric properties of different anti-UV stabilized EVA plastic films. Acta Hortic. 956, 515-522. https://doi.org/10.17660/ ActaHortic.2012.956.61.

Schettini, E., Stefani, L., and Vox, G. (2014). Interaction between agrochemical contaminants and UV stabilizers for greenhouse EVA plastic films. Appl. Engin. in Agric. 30(2), 229-239. https://doi. org/10.13031/aea.30.10048.

Shklyar, A., and Arbel, A. (2004). Numerical model of the threedimensional isothermal flow patterns and mass fluxes in a pitchedroof greenhouse. J. Wind Engin. and Industr. Aerodyn. 92, 10391059. https://doi.org/10.1016/j.jweia.2004.05.008.

Selma, M.V., Luna, M.C., Martínez-Sánchez, A., Tudela, J.A., Beltrán, D., Baixauli, C., and Gil, M.I. (2012). Sensory quality, bioactive constituents and microbiological quality of green and red freshcut lettuces (Lactuca sativa L.) are influenced by soil and soilless agricultural production systems. Postharv. Biol. Technol. 63(1), 1624. https://doi.org/10.1016/j.postharvbio.2011.08.002.

Sonneveld, C., and Voogt, W. (2009). Plant Nutrition of Greenhouse Crops. (New York: Springer). https://doi.org/10.1007/978-90-4812532-6.

Soriano, T., Montero, J.I., Sanchez-Guerrero, M.C., Medrano, E., Antón, A., Hernández, J., Morales, M.I., and Castilla, N. (2004). A study of direct solar radiation transmission in asymmetrical multispan greenhouses using scale models and simulation models. Biosyst. Engin. 88(2), 243-253. https://doi.org/10.1016/j.biosystemseng.2004.03.006.

Soto, F., Gallardo, M., Thompson, R.B., Peña-Fleitas, M.T., and Padilla, M. (2015). Consideration of total available $\mathrm{N}$ supply reduces $\mathrm{N}$ fertilizer requirement and potential for nitrate leaching loss in tomato production. Agric. Ecosyst. Environ. 200, 62-70. https://doi. org/10.1016/j.agee.2014.10.022

Stanghellini, C., Baptista, F., Eriksson, E., Gilli, C., Giuffrida, F., Kempkes, F., Muñoz, P., Stepowska, A., and Montero, J.I. (2016). Sensible use of primary energy in organic greenhouse production BioGreenhouse COST Action FA 1105. www.biogreenhouse.org. https://doi.org/10.18174/373582

Stefani, L., Zanon, M., Modesti, M., Ugel, E., Vox, G., and Schettini, E. (2008). Reduction of the environmental impact of plastic films for greenhouse covering by using fluoropolymeric materials. Acta Hortic 801, 131-138. https://doi.org/10.17660/ActaHortic.2008.801.9.

Teitel, M., Ziskind, G., Liran, O., Dubovsky, V., and Letan, R. (2008). Effect of wind direction on greenhouse ventilation rate, airflow patterns and temperature distributions. Biosyst. Engin. 101, 351369. https://doi.org/10.1016/j.biosystemseng.2008.09.004.
Thompson, R.B., Martínez-Gaitan, C., Gallardo, M., Giménez, C., and Fernández, M.D. (2007). Identification of irrigation and N management practices that contribute to nitrate leaching loss from an intensive vegetable production system by use of a comprehensive survey. Agric. Water Mgt. 89, 261-274. https://doi.org/10.1016/j. agwat.2007.01.013.

Tüzel, Y. (2013). Cultural practices. In Good Agricultural Practices for Greenhouse Vegetable Crops. Principles for Mediterranean Climate Areas, W. Baudoin, N. Castilla, and M. Qaryouti, eds. (Rome, Italy: FAO Publications), p. 379-397.

Tüzel, Y., and Oztekin, G.B. (2015). Protected cultivation in Turkey. Chronica Hortic. 55, 21-26.

Tüzel, Y., and Oztekin, G.B. (2016). Recent developments in protected cultivation of Turkey. Acta Hortic. 1142, 435-442. https://doi. org/10.17660/ActaHortic.2016.1142.66.

Tüzel, Y., and Oztekin, G.B. (2017). Crop diversification, management and practical uses. In GAP for Greenhouse Vegetable Production in the SEE Countries: Principles for Sustainable Intensification of Smallholder Farms, W. Baudoin, S. De Pascale, N. Gruda, L. Urban, and J. Tany, eds. (Rome, Italy: FAO Publications), p. 105-122.

Vanthoor, B., Stanghellini, C., Van Henten, E., and De Visser, P. (2009). The effect of outdoor climate conditions on passive greenhouse design. Acta Hortic. 809, 61-66. https://doi.org/10.17660/ ActaHortic.2009.807.4.

Vox, G., Teitel, M., Pardossi, A., Minuto, A., Tinivella, F., and Schettini, E. (2010). Sustainable Greenhouse Systems (Ch. 1). In Sustainable Agriculture: Technology, Planning and Management, A. Salazar, and I. Rios, eds. (NY, USA: Nova Science Publishers, Inc. ), p. 1-79. ISBN: 978-1-60876-269-9.

War, A.R., Sharma, H.C., Paulraj, M.G., War, M.J., and Ignacimuthu, S. (2011). Mechanisms of plant defense against insect herbivores. Plant Signal Behav. 6(12), 1973-1978. https://doi.org/10.4161/ psb.6.12.18053.

Wohanka, W. (2002). Nutrient solution disinfection. In Hydroponic Production of Vegetables and Ornamentals, D. Savvas, and H.C. Passam, eds. (Athens, Greece: Embryo Publications), p. 345-372.

Received: Nov. 17, 2017

Accepted: Apr. 18, 2018

Addresses of authors:

J.A. Fernández ${ }^{1}$, F. Orsini² ${ }^{2}$ E. Baeza ${ }^{3}$, G.B. Oztekin ${ }^{4}$,

P. Muñoz ${ }^{5}$, J. Contreras ${ }^{1}$ and J.I. Montero ${ }^{5}$

${ }^{1}$ Producción Vegetal, E.T.S. Ingeniería Agronómica,

Universidad Politécnica de Cartagena, Cartagena, Spain

${ }^{2}$ Research Centre on Urban Environment for Agriculture and Biodiversity, Agricultural Sciences Department, Alma Mater Studiorum, University of Bologna, Bologna, Italy ${ }^{3}$ Wageningen UR, Greenhouse Horticulture, Wageningen,

The Netherlands

${ }^{4}$ Ege University, Faculty of Agriculture, Department of Horticulture, Bornova-Izmir, Turkey

${ }^{5}$ Institut de Recerca i Tecnología Agroalimentaries, Cabrils, Spain 